\title{
OPERATIONS OF THE INSTITUTION OF BAITUL MAL WA AT-TAMWIL UNDER THE PERSPECTIVE OF AL-KULLIYAT AL-KHAMSAH OF THE AL-SHATIBI'S MAQASID AL-SHARI'AH
}

\author{
Iftihor \\ STAI Nazhatut Thullab \\ iftihor.kacong@gmail.com
}

\begin{abstract}
The development of the Islamic economics in Indonesia shows progress and needs to be appreciated. It can be seen in the effort to find its relevance to the modern economy, including the application of maqașid shari'ah as the main support in every operational development of shari'ah financial institutions. In this study, researcher will focus on the issue of how to implement the maintenance of alkulliyyāt al-khamsah of maqāid shari'ah of al-Shatibi at BMT Mawaddah Pelenggagan, Pamekasan, Madura. This is a qualitative research that the data is gained by using documentation and interview technique. The results of this study are (1) the implementation of maintenance of maqàsid shari'ah of al-Shatibi's alkulliyyat al-khamsah which has been carried out by BMT Mawaddah has been going well. (2) There are several patterns that are not implemented because there are obstacles in their implementation. (3) It is found that there is a form of conformity between the concept of maqāsid shari'ah in general and that of al-Shatibi's alkulliyyāt al-khamsah.
\end{abstract}

Keywords: Maqāṣid sharīah of al-Shātibí, al-kulliyy āt al-khamsah

\begin{abstract}
Abstrak: Perkembangan ekonomi shari 'ah di Indonesia menunjukkan kemajuan yang patut disyukuri dan diapresiasi, nampak pada ikhtiar untuk mencari relevansinya dengan ekonomi modern. Termasuk dalam penerapan maqāsid shari 'ah sebagai sandaran utama dalam setiap pengembangan operasional lembaga keuangan shari'ah. Dalam penelitian ini, peneliti akan focus pada persoalan bagaimana implementasi pemeliharaan maqāsid sharī'ah al-Shàtibì dalam prespektif al-kulliyyāt alkhamsah di BMT Mawaddah Pelenggagan Pamekasan, Madura. Adapun metode jenis penelitian yang peneliti gunakan adalah jenis penelitian kualitatif dengan menggunakan tehnik dokumentasi dan interview (wawancara). Hasil dari penelitian ini, ditemukan bahwa (1) implementasi pemeliharaan terhadap maqāsid sharīah al-Shātibì perspektif al-kulliyyāt al-khamsah yang dilakukan oleh BMT Mawaddah sudah berjalan dengan baik. (2) terdapat beberapa pola yang tidak terlaksana karena terdapat hambatan dalam pelaksanaannya. (3) ditemukan bahwa terdapat bentuk

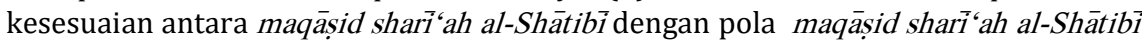
perspektif al-kulliyyāt al-khamsah yang dilaksanakan.
\end{abstract}

Kata Kunci: Maqāṣid sharī'ah al-Shātibìi, al-kulliyyāt al-khamsah

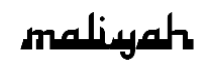

Jurnal Hukum Bisnis Islam

Volume 11, Nomor 02, Desember 2021

p-ISSN: 2088-4869/ e-ISSN: 2597-4351 
Operations Of The Institution Of Baitul Mal Wa At-Tamwï ...

\section{Introduction}

The course of Islamic economics and finance has crossed various ages and times and it has faced different transitions of civilization. At the beginning of its history of development, Islam was equipped with economic system to regulate economic activity at that time. ${ }^{1}$ It was the change in the pioneers of civilization that made Islam lagging behind, when the world was progressing so rapidly. The West is the pioneer of a new civilization, it is here to contribute endlessly, comes up with various achievements, and gives a new color to the life of the modern world.

The achievements and contributions of the West to the world should be appreciated, but on the other hand, these achievements seem to be a new problem for global life, because they cause inequality and imbalance in global life itself. The economic system of capitalism is a system that operates based on Western ideology, with individualistic, hedonistic and destructive views. ${ }^{2}$ We already know that the capitalist economic system is not able to provide solutions to socioeconomic inequality. On the contrary, it creates and perpetuates these inequalities and disparities to maintain their existence. Even the interest system in the capitalist economic system is suspected as the cause of the crisis. Then the Islamic economic system came back and began to be looked at as an alternative solution and choice and is expected to be able to answer the world's socio-economic problems in the future.

Islamic banking and shari'ah financial institutions, as the embodiment of Islamic economic institutions, have proven to be able to withstand the storm of crisis occurred. This

1 Muhammad, Ekonomi Islam, Kontribusi Fundamentalisme Islam untuk Ekonomi Islam, (Malang: Empatdua, 2009) and Adiwarman Azwar Karim, Sejarah Pemikiran Ekonomi Islam, (Jakarta: PT Raja Grafindo Persada, 2006).

${ }^{2}$ Ayief Fathurrahman, "Pendekatan Maqasid Shari'ah: Konstruksi Terhadap Pengembangan Ilmu Ekonomi dan Keuangan Islam”, Hunafa: Jurnal Studia Islamika, Vol. 11, No. 2 (Desember 2014), 194.

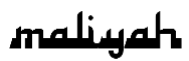


immunity spurs the high level of public confidence in the development of the Islamic economy, both at the national and international levels. ${ }^{3}$ The rapid development of the shari'ah economy and business today is very clear, especially in Indonesia. This is proven by the establishment of several shari'ah institutions; shari'ah banking, shari'ah capital market, shari'ah mutual funds, shari'ah pawnshops, shari'ah insurance, shari'ah cooperatives, Baitul Māl wa at-Tamwil (BMT) and others.

The development of shari'ah banking and shari'ah financial institutions is expected to be a solution to the inability of the usurious economic system in dealing with increasingly complex economic problems. More than that, the goal is to achieve global welfare of the people, both in this world and in the hereafter. With reference to the main objectives above, then maqāsid shari'ah must be used as the main support in every operational development of shari'ah bank products and shari'ah financial institutions. As stated by Imam al-Shatibi in his book al-muwāfaqāt fi ushūl al-shari'ah that discussing maqāṣid shari'ah is the same as discussing maslahah, because benefit and welfare is the ending point of maqāșid shari'ah itself.

The benefits that will be realized, according to Imam alShatibi are divided into three levels, namely: daruriyāh, häjiyah, and tahsiniyah needs. ${ }^{4}$ Darüriyah is a level of urgent need that must be met, because it can threaten the safety of mankind, both in this world and in the hereafter. There are five things that fall into this category, namely maintaining religion, soul, mind, lineage and property. These five things are in other terms called al-darüriyah al-khamsah or al-kulliyyāt al-khamsah. Hajjiyah is a secondary need that does not threaten the safety of

\footnotetext{
${ }^{3}$ Ayief Fathurrahman, "Meninjau Ulang Landasan Normatif Perbankan Shari'ah Di Indonesia: Telaah Atas Teori Kontruksi Fikih Klasik", Jurnal Mawarid, Vol. XI, No. 1 (Februari-Agustus, 2010), 6.

4 Abu Ishaq al-Shatibi, Al-Muwafaqat (Saudi Arabia: Wizarah Syuun alIslamiyah), vol. 1, 7.
} 
mankind, but it will experience difficulties. Tahsiniyah is a level of need that does not threaten the existence of any of the five points above and also does not cause difficulties. ${ }^{5}$

One of the shari'ah financial institutions that has implemented the maintenance of maqāșid shari'ah is BMT Mawaddah Palengaan, Pamekasan, Madura. So in this study, the author will focus on a review of shari'ah economic law on the implementation of maintenance of maqāsid shari'ah of alShatibi in BMT Mawaddah, Palengaan, Pamekasan, Madura in the perspective of al-kulliyyāt al-khamsah.

\section{Concept of Maqāṣid Shari'ah}

Terminologically, maqāsid shari'ah comes from two words, namely the words maqāsid and al-shari'ah. Maqāsid means intent and purpose, ${ }^{6}$ taken from the word qașadayaqșudu. ${ }^{7}$ The word maqāsid is the plural form of the word maqsud, which is something that becomes an object or target, so that it can be interpreted with a purpose. While the word alshari'ah means law or legislation. ${ }^{8}$ The word al-shari'ah can also be interpreted as a path to a water source. ${ }^{9}$ The road to this water source can also be interpreted as the road to the main source of life. ${ }^{10}$

Meanwhile, according to Yusuf al-Qaradiawi, the word alshari'ah comes from the word shara'a, which means to explain or explain something or also comes from the word shir'ah which means a place that is used as a means to take water

\footnotetext{
${ }^{5}$ Galuh Nashrullah, "Konsep Maqasid al-Shari'ah dalam Menentukan Hukum Islam: Perspektif al-Shatibi dan Jasser Auda", Al-Iqtishadiyah, Vol. 1, No. 1 (Desember 2014), 54-55.

${ }^{6}$ Ahmad Warson Munawwir, Kamus Al-Munawwir Arab-Indonesia Terlengkap (Surabaya: Pustaka Progessif, 1997), 1124.

${ }^{7}$ Atabik Ali, Kamus Kontemporer, (Yogyakarta: Yayasan Ali Maksum, Multi Gaya Grafika, 1996), 1454.

${ }^{8}$ Ibid, 712.

${ }^{9}$ Ibnu Mansur al-Afriqi, Lisan al- 'Arab (Beirut: Dar as-sadr, tt), 175.

${ }^{10}$ Fathur Rahman, Islam, alih Bahasa Ahsin Muhammad, ( Bandung: Pustaka, 1984 ), 140
} 
directly so that the person who takes it does not need the help of other tools. ${ }^{11}$ Maqāsid Shari'ah is the goal of all provisions of Allah SWT that are prescribed to mankind. As explained by Ali al-Sāyis that shari'ah is a law given by Allah SWT to His servants so that they believe and practice it for their benefit in this world and the hereafter. ${ }^{12}$

Imām al-Shātibì explained about the term maqāṣid shari'ah in one of his phenomenal works, namely the book almuwafaqāt fi uṣul al-shari'ah, that in fact, the shäri' (Allah SWT) establishes shari'ah to realize and actualize the benefit of the world and the hereafter. This is also in line with Fathi alDăraini. He said that a law was not made for the law itself, but for another purpose, namely benefit. ${ }^{13}$ Likewise, according to Abu Zahrā that the essential purpose of Islamic law is benefit. ${ }^{14}$ This goal can be traced in the verses of the Qur'an and alHadith as a logical reason for the formulation of a law that is oriented to human benefit. 15 The benefit that is the goal of shari'ah is limited to five main components, namely religion, soul, reason, lineage and property. Everything that contains the maintenance of these five components is called maslahah and anything that causes the loss of these five components is called mafsadah. ${ }^{16}$

Maintaining religion at the dâruri (primary) level in maintaining religion (hifz al-din) in maqāṣid shari'ah is the implementation and maintenance of primary religious obligations such as the prohibition of eating carrion, blood,

\footnotetext{
${ }^{11}$ Yusuf Qardawi, Membumikan Shari'at Islam, (Bandung: Pustaka Mizān, 2003), 13.

12 Ali al-Sayis, Nashi'ah al-Fiqh al-Ijtihad wa atwaruh, (Kairo :Majma' alBuhüts al-Islamiyah,1970), 8.

${ }^{13}$ Fathi al-Daraini, al-Manahij al-Ushuliyah, (Damsyik: Dar al-Kitab al-Hadits, 1975), 28.

${ }^{14}$ Muhammad Abu Zahra, Ushul al-Fiqh, (Mesir : Dar al-Fikr al-'Arabi, 1958), 366.

${ }^{15}$ Satria Effendi, Ushul Fiqih, ( Jakarta: Kencana, 2005), 233.

${ }^{16}$ Muhammad Said Romadhan al-Buthi, Dawa.bit al Maslahah fi al-Shari'ah alIslamiyah, (Beirut: Dar al-Muttahidah, 1992), 110.
} 
pork and so on. Failure to carry out this primary level can threaten the existence of religion at least for religious individuals. Maintaining the religion of hifz al-din in maqāșid shari'ah is described in Q.S. al-Maidah: 3 which means:

"Forbidden to you are carrion, blood, and swine; what is slaughtered in the name of any other than Allah; what is killed by strangling, beating, a fall, or by being gored to death; what is partly eaten by a predator unless you slaughter it; and what is sacrificed on altars. You are also forbidden to draw lots for decisions. This is all evil. Today the disbelievers have given up all hope of 'undermining' your faith. So do not fear them; fear Me! Today I have perfected your faith for you, completed My favour upon you, and chosen Islam as your way. But whoever is compelled by extreme hunger-not intending to sin-then surely Allah is All-Forgiving, Most Merciful.".

Maintaining the soul in the daruri (primary) level in the maintenance of the soul (hifz al-nafs) in maqașid shari'ah is qisas stipulation for the survival of human life as a whole, so that humans do not easily take the lives of others. This is illustrated in Q.S. al-Baqarah: 178-179 which means:

"O believers! 'The law of' retaliation is set for you in cases of murder - a free man for a free man, a slave for a slave, and a female for a female. But if the offender is pardoned by the victim's guardian, then blood-money should be decided fairly and payment should be made courteously. This is a concession and a mercy from your Lord. But whoever transgresses after that will suffer a painful punishment. There is 'security of' life for you in 'the law of' retaliation, 0 people of reason, so that you may become mindful 'of Allah".

Maintaining the mind in the daruri (primary) level to the maintenance of reason (hifz al-'aql) in maqāsid shari'ah is like a prohibition on consuming goods that can damage common 
sense such as liquor and all kinds of drugs. ${ }^{17}$ As explained in Q.S. al-Baqarah verse 219 which means:

"They ask you 'O Prophet' about intoxicants and gambling. Say, "There is great evil in both, as well as some benefit for people-but the evil outweighs the benefit." They 'also' ask you '0 Prophet' what they should donate. Say, "Whatever you can spare." This is how Allah makes His revelations clear to you 'believers', so perhaps you may reflect".

Maintaining offspring at the daruri (primary) level in maintaining offspring (hifz al-nasl) in maqașid shari'ah is the law of marriage and forbidding adultery. Marriage has proven to be an effective way of legally continuing the process of continuing generations. Adultery, according to shara' norms, destroys the sacredness of relationships with the opposite sex, and breaks kinship ties. The provisions regarding marriage are regulated in such a way as to meet the pillars requirements, so that the marriage becomes valid and is not considered adultery. ${ }^{18}$ One of the arguments is illustrated in Q.S. al-Nis $\bar{a}$ : 34 which means:

"If you fear you might fail to give orphan women their 'due' rights 'if you were to marry them', then marry other women of your choice-two, three, or four. But if you are afraid you will fail to maintain justice, then 'content yourselves with one or those 'bondwomen' in your possession. This way you are less likely to commit injustice. Give women 'you wed' their due dowries graciously. But if they waive some of it willingly, then you may enjoy it freely with a clear conscience.".

Maintaining offspring at the daruri (primary) level in maintaining property (hifz al-mal) in maqạsid shari'ah is like a

\footnotetext{
${ }^{17}$ Khoirul Amin, "Implementasi Maqasid al-Ahkam Terkait Rekonstruksi Hukum Islam Indonesia”, Mlangi, Vol. 2, No. 2, (Desember 2014), 9-10. ${ }^{18}$ Ismaīl Muhammad Syah, dkk, Filsafat Hukum Islām, (Jakarta: Bumi Aksara.1992), 87.
} 
prohibition against the practice of usury and the prohibition of eating usury property, as stated in Q.S. Ali Imran: 130 which means:

"O believers! Do not consume interest, multiplying it many times over. And be mindful of Allah, so you may prosper".

Imam Shātibī, in this case, is a pioneer in formulating maqāsid shari'ah in a systematic and comprehensive manner. ${ }^{19}$ Classical scholars often used short expressions to refer to maqāsid shari'ah, such as al-hikmah, al-mașälih, al-aghard, alghäyah, al-asrär, al -ahdäf and so on. A comprehensive discussion of maqāsid shari'ah has only been carried out by contemporary maqāsid scholars, such as Imam Shātibī and others. ${ }^{20}$

Imām al-Bannan interprets maqāṣid sharī'ah with legal wisdom (hikmat al-hukm), Imām al-Samarqandi equates it with legal meanings (ma'āni al-hukmi), Imām al-Asnawi interprets it with legal purposes (maqāṣid al-hukm), while Imām al-Ghāzali, Imām al-Amidì and Imām Ibn al-Hājib defines it by achieving benefits (jalb al-mașāleh) and rejecting mafsadat (dar' almafașid). The variation in this definition indicates that there is a close relationship between maqāșid shari'ah with wisdom, illat, purpose and benefit, ${ }^{21}$ because the ultimate goal of a sharia'ah law is one, namely mashlahah and the welfare of mankind. 22

\section{Implementation of Maqạsid Sharïah within the Shari'ah Financial Institution}

\footnotetext{
${ }^{19}$ Ahmad Imam Mawardi, Fiqh Minoritas fiqh al-Aqliyat dan Evolusi Maqashid al-Syari'ah dari konsep ke pendekatan, (Yogyakarta: Lkis, 2010) 180.

${ }^{20}$ Adhi Maftuhin, dkk., Gerbong Pemikiran Islam II (Kairo: An-Nahdlah Press, 2016), 5.

${ }^{21}$ Ahmad Imam Mawardi, Fiqh Minoritas fiqh al-Aqliyat dan Evolusi Maqashid al-Syari'ah dari konsep ke pendekatan, (Yogyakarta: Lkis, 2010), 180.

22 Muhammad Khalid Mas'ud, Filsafat Hukum Islam dan Perubahan Sosial, translated by Yudian W. Asmin, (Surabaya: al-Ikhlas, 1995), 225.
} 
Shari'ah financial institutions are one of the basic human needs. This is, of course, very much needed by humans in order to fulfill their needs in accordance with the rules of Islamic shari'ah. In the application of Islamic law, there are at least two things behind the role of maqāsid shari'ah in determining every law, especially the determination of laws relating to Islamic economic activities, especially in shari'ah financial institutions, namely:

1. The progress of the times which is marked by the existence of modern economic transactions that never existed at the time of the Prophet or the absence of a clear underlying argument, then maqāsid shari'ah can be used by mujtahids in creating Islamic law that is elastic and flexible to suit the times.

2. The revival of Islamic economic discourse which has now reached the practical level and the rise of elastic and flexible law based on maqașid shari'ah, is expected to increase the belief of Muslims that the shari'ah he believes is in accordance with the times and all circumstances (șalih likulli zamān wa makan). ${ }^{23}$

The implementation of maqāsid shari'ah in the economic field, especially shari'ah financial institutions, has been carried out by Muslim economists. One of the implementation products is the Maqasid Shari'ah Index (MSI), a tool used to determine the performance of a company by using maqāsid shari'ah as the basis for its footing. The company's performance measurement has been carried out using financial ratios such as Economic Value Added (EVA) and Capital, Asset, Management, Earning, Liquidity (CAMEL). However, performance measurement viewed from the financial sector alone still has weaknesses,

23 Zaki Zamani, "Urgensi Maqasid al-Shari'ah dalam Manajemen Perbankan Shari'ah ", JES, Vol. 1, No. 2 (Maret, 2017), 292. 
because it ignores non-financial factors which in reality have a positive impact on long-term financial performance. ${ }^{24}$

The development of Indonesian Islamic Economy has been very significant in the last fifteen years, both theoretically and practically. The Shari'ah Economics Faculty is often found in several universities. Scientific works in the form of books and journals as well as shari'ah banks, shari'ah cooperatives, shari'ah pawnshop, BMT and sharia financial institutions are easy to find. However, along with this development, the study of Islamic economics from the maqașid shari'ah perspective can still be said to be small in number. ${ }^{25}$

Muhammad Syafii Antonio revealed that the maqașid shari'ah study in Islamic economics is a very interesting topic and is becoming a trend in Islamic economic and financial development, such as the realization of the maqasid index in testing the performance of Islamic banks. In addition, maqāsid shari'ah is also a discipline that has long been developed by the prior Muslim scholars such as Imām Juwainī, Imām Ghazali, Imām Shātibī, and Ibn 'Ashūr. However, most of these studies are only focused on issues of worship, such as the work of alTirmizịi al-Hākim "As-Shalātu wa Maqāșiduhā" or the work of al-'Iz bin Abdu al-Salām. "Maqạșid al-Ibādah".26 The growth of Shari'ah Financial Institutions (LKS) continues to progress such as Bank Muamalat which has been established since 1992 and is followed by the other LKS, such as Shari'ah Pawnshops, Shari'ah Insurance, Shari'ah Mutual Funds, Shari'ah Hotels, BMT and so forth. ${ }^{27}$

\section{Profile of the BMT Mawaddah}

\footnotetext{
${ }^{24}$ Budi Sukardi, dkk, “Inklusivisme Maqashid Shari'ah Menuju Pembangunan Berkelanjutan Bank Shari'ah di Indonesia”, Tsaqafah, Vol. 12, No. 1 (Mei 2016), 213.

${ }^{25}$ Zainil Ghulam, "Implementasi Maqasid Shari'ah dalam Koperasi Shari'ah", Iqtishoduna, Vol. 7, No. 1 (April, 2016), 92.

26 Muhammad Syafii Antonio, Maqasid Shari'ah dalam Ekonomi Islam, (Yogyakarta: Smart WR, 2014), v-vi.

${ }^{27}$ Ibid, 94.
} 
Bait al-Màl wa at-Tamwil (BMT) Mawaddah is a business unit engaged in the economy under the auspices of the $\mathrm{Al}$ Iqthisad lil-Muamalah Cooperative (KOIM) Mawaddah shari'ah of East Java. Starting from the establishment of KOIM in 1993, which was precisely formed in April 1993 and received legality from the Ministry of Cooperatives on May 17, 1994 with a legal entity number: 7754/II/1994 and SK amendments to the articles of association with the number: 1/LAP-PAD/I/2017 on January 27, 2017.

The idea of establishing KOIM itself emerged after the caretaker of the Miftahul UlumIslamic Boarding School in Panyepen which at that time was under the care of $\mathrm{RKH}$ Muddatsir Badruddin. He sent one of his students to attend a training in Jakarta. This idea was then reaffirmed by holding a cooperative establishment meeting at the Miftahul Ulum Islamic Boarding School in Panyepen. Palengaan, Pamekasan, Madura which was attended by 5 people.

Since the first year of the establishment of the KOIM Cooperative, there has been no activity and it can be said to be a vacuum, until the time came on January 2, 1999. The KOIM Cooperative was operational in the Shari'ah Financial Services Unit (UJKS). Furthermore, in September 2015 the Ministry of Cooperatives issued a new regulation on the implementation of Shari'ah Savings and Loans Cooperatives (KSPPS) No. 10 of 2015 and No. 14 of 2015 concerning KSPPS accounting and No. 16 of 2015 concerning KSPPS. In the 2015 RAT, it was approved to change the name from the Shari'ah Financial Services Cooperative (KJKS) KOIM Mawaddah to the Savings and Loans and Financing Cooperative (KSPPS) and continued the Extraordinary Member Meeting to change the articles of association from KJKS KOIM to KSPPS Cooperative KOIM Mawaddah Shari' ah East Java.

The Shari'ah Savings and Loans and Financing Unit (USPPS) or BMT Mawaddah is here as a solution to the real conditions of the community which, when viewed from an economic perspective, have not been able to live properly and 
steadily. There are still many people who are often entangled in transactions with moneylenders so that instead of improving people's living standards, it adds to the burden of their lives. Previously, there were no institutions that could help improve the welfare of the wider community, no bargaining power with other parties and other conditions that were completely unfavorable for the lower middle class. In fact, the potential possessed by the general public if it is managed with a togetherness system, it is almost certain that it will be able to improve the community's economy and prosper their lives.

Bait al-Màl wa at-Tamwìl (BMT) Mawaddah is a representation of a micro-economic shari'ah financial institution which is an asset financial institution for the community with a pattern of togetherness through savings, financing and other activities that have an impact on the community. Improving the economy of the members or customers and partners to a more prosperous level, safe and blessed is one of its tasks. As a shari'ah financial institution, whose mission is to become a socio-economic institution for the community, BMT Mawaddah always improves itself, especially in terms of service quality and management so that it becomes an institution that is in accordance with the vision and mission it carries. This institution is indirectly an asset of the community which in its operational implementation refers to the principles of Islamic shari'ah.

In the history of the establishment of BMT Mawaddah, there was only one branch, which was located at the Miftahul Ulum Islamic Boarding School in Panyepen with simple operations. However, as more and more customers join in BMT Mawaddah, the infrastructure facilities and quality of service are also improved, starting from the use of money counting machines, building construction and all supporting facilities, employee training, and so on.

As time goes by, BMT Mawaddah is growing and advancing rapidly, so in order to develop the business and meet the needs and demands of customers in shari'ah financial

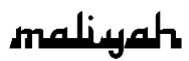


transactions, especially alumni of the Miftahul Ulum Islamic Boarding School, students, guardians of students, all sympathizers or the community, then BMT Mawaddah opened branches in various areas in Madura which until now BMT Mawaddah already has 16 branches.

\section{The Implementation of BMT Mawaddah}

1. Protecting the Religious

In the maintenance of this religion, BMT Mawaddah has several programs with several patterns of maintenance. The followinga are explanations of what patterns have been carried out by BMT Mawaddah in maintaining this religion:

First; BMT Mawaddah provides assistance for the construction and maintenance of worship facilities and infrastructure such as mosques and so on through the BMT Mawaddah social fund. Several mosques that received assistance, including the Jamik an-Nashar mosque, Miftahul Ulum Islamic Boarding House and the Maryam mosque which located in Poto'an Laok Pamekasan. They received funding assistance of Rp. 400,000,000.00,-

The mosque is one of the important symbols for Islam where the congregational prayers are carried out in it. So departing from that, BMT Mawaddah participates in safeguarding and maintaining the mosque to be a proper place to carry out worship, especially the five daily prayers for the people. So that Muslims will always get comfort in carrying out worship activities and other religious activities. By that, then this religion will continue to be maintained by maintaining mosques and prayers.

Second; BMT Mawaddah provides assistance for religious events such as public recitations, commemoration of Islamic holidays and other activities through the participation funds donated to Miftahul Ulum Islamic Boarding School and several Islamic Boarding Schools in Madura and other areas. Third; Payment of Zakat by BMT Mawaddah to the indigent, poor and other al-așnaf altsamaniyah (eight groups), especially the customers of BMT 
Mawaddah themselves who are included in the mustahiq zakah group which is allocated from the profits of BMT Mawaddah as a form of obedience to religious rules. Fourth; the guarantee of every BMT product is a halal product because it is under full supervision by the DPS of BMT Mawaddah and there is a process of product preparation before the publication of the product at BMT Mawaddah.

So the activities mentioned above can be the main differentiator between Islamic financial institutions and conventional financial institutions. So that it gives a good impression to customers and the wider community that Islamic financial institutions such as BMT Mawaddah in carrying out their activities are in accordance with religious norms. So religion is not just a theory, but becomes an implementation and form of obedience to existing rules in religion itself. By conducting all mentioned above, religion is not just a symbol, but it has become a spirit in every daily Muslim activity, so with the maintenance of Islamic teachings, the Islamic religion will be preserved from generation to generation.

2. Maintaining the Property

In maintaining property, BMT Mawaddah has several excellent programs. Based on the data and information that the researcher got, the following will explain what patterns have been carried out by BMT Mawaddah in maintaining assets including:

First, the investment products owned by BMT Mawaddah for customers are mudarabah, deposits and so on. This investment product is intended that people who do not have skills in managing their assets but have the capital can develop the quantity of assets in Islamic ways, such as investing their assets in BMT Mawaddah. Here, BMT Mawaddah gets the trust of the community to manage their assets, so that public funds can continue to develop in a halal manner because it is managed by contract and management in accordance with Islamic religious rules. 
Second, BMT Mawaddah Has its own land or business entity such as a KOIM mini market or supermarket, fashion shop, printing and photocopying, depots and so on. By these, it provides a lot of materials and basic needs to be consumed by the wider community. It is because it already has several branches in several areas in Madura in particular and East Java in general. Besides that, this business has regular customers, namely the students of the Miftahul Ulum Islamic Boarding School which until now numbered thousands of male and female students, on average, of them are customers at BMT Mawaddah. It is clear that customer funds invested in BMT Mawaddah are managed in the real sector so that BMT Mawaddah is able to provide field facts about the halal management of customer assets. This is important to increase people's confidence that their assets are managed in a trustworthy manner and their safety and halal are guaranteed.

Third, there is a DPS that oversees economic activities at BMT Mawaddah. DPS acts as a supervisor at BMT Mawaddah, both in preparing and launching a product that is in accordance with Islamic teachings or financial activities that become routine at BMT Mawaddah. So that, all activities related to law at BMT Mawaddah can be monitored properly. Through this pattern, it will have an impact on the level of trust in Islamic financial institutions of BMT Mawaddah. At the same time, it shows that the institution really maintains the shari'ah of every financial activity and guarantees that the customer's assets will not be mixed with illicit assets due to maysir, gharar, usury, dhulm etc.

Fourth, maintaining the liquidity of BMT Mawaddah. That liquidity is a very fatal thing in a shari'ah financial institution. In order to maintain customer needs for their assets back when customers need their assets, BMT Mawaddah always does financial planning. This is evident from the detailed reports and financial targets contained in the annual RAT whose graph is always increasing. From 
there it will be easy to see that BMT Mawaddah really maintains its liquidity so that people can easily withdraw their funds at any time with the amount they need.

Fifth, planning the budget for BMT Mawaddah funds properly and correctly can also be seen in details of financial activities and financial targets for the next year through the BMT Mawaddah's annual RAT book. This is aimed at maintaining the customer's assets properly and safely. Sixth, there is a passbook and proof of other transactions such as receipts and so on in controlling debits, credits and proof of payments. This is done by BMT Mawaddah to maintain transparency of transaction activities, so that customer assets are maintained safely.

Seventh, there is the RAT (Annual Member Meeting) of BMT Mawaddah, which is attended by all members, staff, administrators, supervisors. This is done by BMT Mawaddah in dealing with the transparency of the assets of members and customers as well as the assets of the institution. By these they can be controlled and be transparent to avoid negative things and is of course free from unscrupulous persons in the assets of members, customers and assets of BMT Mawaddah. Eighth, it is carrying out audits in each unit of BMT Mawaddah regularly, at least once every three months. This is done by BMT Mawaddah in order to maintain the security of customer assets so that their security is maintained from cash leaks or misappropriation of persons.

Ninth, there is the implementation of periodic monitoring and evaluation to all BMT Mawaddah branches with a self-assessment pattern as a preventive measure. This is also done by BMT Mawaddah to minimize nonperforming financing, so that the development and maintenance of customer assets can be well-maintained and developed as expected and its liquidity is maintained. Tenth, a monthly evaluation meeting is held with the management and the existing managers. This is done by BMT Mawaddah with the aim of improving the quality of 
management and efforts to avoid mistakes as well as improving systems and programs that are not running well, so that the stability of BMT Mawaddah can be maintained and the development of customer assets can be well controlled.

3. Protecting the Mind

In the maintenance of sense, BMT Mawaddah has several programs with several patterns of maintenance. The researcher will explain what patterns have been carried out by BMT Mawaddah in the maintenance of the human mind, namely:

First, the real assistance of BMT Mawaddah for education likes appreciating of end-of-year souvenirs of the educational calendar and providing scholarships. This is done by BMT Mawaddah as a contribution and appreciation for the progress of human resources and as a stimulant so that education in Indonesia, especially in Madura, continues and the human mind is maintained. With this program, BMT Mawaddah hopes that public education, especially future generations, will continue to be preserved. The pattern taken by BMT Mawaddah in maintaining reason includes giving appreciation in the form of giving souvenirs in several educational places at the end of the educational calendar year, especially education at the Miftahul Ulum Islamic Boarding School itself and some religious instututions in other areas.

In addition, BMT Mawaddah also provides scholarships for education ranging from undergraduate (s1) to postgraduate (s2). Many students at various universities receive scholarships, especially those who excel in previous education and on average those who receive educational scholarship are the alumni of Miftahul Ulum Islamic Boarding School. Later, they will be appointed as employees or staff either by BMT Mawaddah itself or Miftahul Ulum Islamic Boarding School.

Second, BMT Mawaddah provides education on Islamic products to customers and to prospective customers in 
particular, so that they understand the products of Islamic financial institutions, especially those of BMT Mawaddah. In a straightforward and comprehensive manner, the employees of BMT Mawaddah will explain about the product and the mechanism of the product and matters related to BMT Mawaddah, so that when the prospective customers and the customers understands about the products available at BMT Mawaddah, they are ready to use the products owned by BMT Mawaddah, such as savings products, financing products and investment products. So with the program and employee obligations in providing explanations about BMT Mawaddah products, they will be interested to the products of it. From this, the researcher concluded that indirectly, BMT Mawaddah participated in educating and contributing knowledge for the wider community.

Third, BMT Mawaddah participates in providing assistance to educational institutions, especially formal Islamic schools and Islamic boarding schools under the management of the Miftahul Ulum. It is because the average BMT Mawaddah customers are students of Miftahul Ulum Islamic Boarding School so that the benefits return to them again. This is intended that teaching and learning activities in educational institutions of the Islamic boarding house continue to run well with adequate learning facilities so as to create an educated society.

Fourth, BMT Mawaddah provides scientific research opportunities for undergraduate, postgraduate and other students who want to do research about BMT Mawaddah. And the results of this research can be used by directors, employees, customers and all staff of BMT Mawaddah as consideration or reference or even evaluation in developing BMT Mawaddah.

Fifth, BMT Mawaddah conducts socialization, counseling and promotion about shari'ah economics, such as introduction of sharia products, the importance of saving, investment awareness, halal transactions. All of these are 
carried out by the formal and non-formal education units / Islamic boarding schools / institutions and non-formal education units and the wider community with the aim that they becomes aware and understand about the mechanisms, objectives, vision and mission of the Islamic financial institutions and provides awareness and understanding of the importance of saving.

Sixth, BMT Mawaddah carries out education, seminars, workshops and trainings for new and old employees about the mechanism for carrying out BMT activities properly and correctly. This is none other than a strategy to increase internal human resources owned by BMT Mawaddah. Several things that have been done are appraisal training gold, training on financing products, savings and so on. These activities become a routine agenda and are carried out by BMT Mawaddah at the end of every month. With the agenda, it is hoped that it will increase the understanding of employees, administrators, supervisors and overall staff as well as improve the human resources of BMT Mawaddah managers.

Seventh, BMT Mawaddah cooperates with the campus or the Miftahul Ulum Islamic High School (STAIMU) in in several ways, especially matters related to payments and finances. In this program, every student has obligation to pay tuition fees through BMT Mawaddah. Cooperation like this can help create efficiency and effectiveness in student payments to educational institutions, so that the process of learning and teaching on campus and high schools can still run well.

Eighth, BMT Mawaddah collaborates with the al-Miftah Magazine organization, an Islamic magazine engaged in da'wah through writing. BMT Mawaddah helps with marketing and sales of the al-Miftah Magazine. What is done by BMT Mawaddah is hoped that the wider community can enjoy and consume Islamic readings.

4. Maintaining the Soul 
Caring for the soul is the fourth maqașid shari'ah of the five daruriyyat things that must be maintained in order to create benefit and avoid harm to humans in this world and the hereafter. In the maintenance of this soul, BMT Mawaddah has several programs with several patterns of maintenance. Among the explanations of the patterns that have been carried out by BMT Mawaddah in the maintenance of the human soul are as follows:

First, BMT Mawaddah manages savings funds and other customer funds in a safe, halal and professional manner. It aims to provide peace of mind to customers in entrusting their assets to BMT Mawaddah. Second, BMT Mawaddah strives to maintain the cleanliness of the environment around BMT Mawaddah properly, programmed, and scheduled. The application of this cleanliness is aimed for employees, especially in the BMT Mawaddah area, indoors and outdoors with a pattern of implementing a daily cleaning schedule. This is done by BMT Mawaddah in order to help maintain the health of the wider community. In accordance with the health motto is "prevention is better than cure". By maintaining of this cleanliness is expected to prevent the arrival of various diseases such as diarrhea, the growth of dengue fever mosquitoes, malaria mosquitoes and so on.

Third, the area and rooms of BMT Mawaddah are equipped with CCTV so that they are always monitored and recorded for all indoor and outdoor activities of BMT Mawaddah. This aims to provide comfort and security for assets, employees and customers, so that customers feel conducive and safe environment. Fourth, BMT Mawaddah applies special rules for employees and all staff including the prohibition of smoking in the workspace, prohibition of being involved in crimes such as drugs and other addictive substances. The regulation is expected to be able to maintain the mental and health of employees and staff as a whole, especially the souls of customers, will be well maintained. 
Fifth, at BMT Mawaddah there are demands to behave, dress and communicate well and politely, especially to customers. This will make customers feel comfortable and at ease while in the room and environment of BMT Mawaddah. Sixth, BMT Mawaddah has a social service program (baksos) in the environment around BMT Mawaddah with a mutual cooperation pattern. Activities are carried out by employees and the surrounding community at least once a year. This is aimed to providing awareness of the importance of environmental cleanliness to the wider community and helping to improve environmental hygiene, so that the health of employees and the community can be maintained properly.

5. Preserving Offspring

Among the benefits of the world is the maintenance of human existence and the maintenance of lineage. In the maintenance of this offspring, BMT Mawaddah has several programs with several patterns of maintenance. Based on the data and information that the researcher got, the following will explain what patterns have been carried out by BMT Mawaddah in the maintenance of human offspring:

First, BMT Mawaddah has a financing product, by providing business capital assistance so that the lower middle class who has a business can run their business by using this capital. This will be able to create a prosperous family and be able to continue the existence of family life and their descendants. Second, providing assistance to orphans, especially those who stay in Miftahul Ulum Islamic boarding school through zakat funds and social funds. With such assistance, it is hoped that it can help ease the burden of life and provide the ability to continue the existence of the child and his descendants later.

Third, BMT Mawaddah does not employ minors in any way, this is done as a form of avoiding exploitation of offspring. Fourth, BMT Mawaddah maintains the safety of employees' workplaces through building maintenance programs and employee work facilities such as vehicles. 
This is intentionally done in order all employees can maintain their safety and also maintain their lives. And Fifth, BMT Mawaddah guarantees the management of funds in a halal and syar'i way because then the customer's assets become a blessing and have a good impact on the family and descendants who are supported by their savings funds.

6. Maintenance Pattern Not Implemented

BMT Mawaddah has tried to give the best to serve customers and seek things for the benefit of customers and keep away things that can harm customers. However, there are some things that have not been realized until now. Therefore, in the future it will always be pursued as the maximum effort of BMT Mawaddah in serving the needs and benefits of the many people. Among the things that have not yet existed and have not been realized at BMT Mawaddah are:

First, there are no security officers (security guards, etc.). This has not been realized properly because BMT Mawaddah believes that the funds entrusted to BMT Mawaddah are community funds and will be jointly guarded by the community. Even though several BMT Mawaddah parties have tried to do it through evaluation meetings, both monthly, quarterly and annual BMT Mawaddah meetings, it has not yet been realized. Second, BMT Mawaddah did not activate the Hajj and Umrah savings and travel programs managed by BMT Mawaddah. This is because at the Miftahul Ulum Islamic Boarding School, there is already Hajj and Umrah travel, namely Madani travel belonging to Miftahul Ulum Islamic Boarding School.

Third, BMT Mawaddah does not accept students or internship students because there are no appropriate activities and roles that can be submitted to students or interns in carrying out economic transaction activities at BMT Mawaddah. In addition, to keep the internal secrets of BMT Mawaddah and to keep other unwanted things. Fourth, BMT Mawaddah does not yet have an insurance 
product, although in fact BMT Mawaddah has attempted to have this product because it is hampered by the complete requirements for procuring insurance products. Fifth, BMT Mawaddah does not yet have an e-transaction system or online transaction because it is hampered by the amount of tax payments and avoids cooperation with non-shari'ah financial institutions.

7. The Operation of BMT Mawaddah under the Perspektif of al-Kulliyyāt al-Khamsah within al-Shätibi's Concept of Maqāsid Shari'ah

One of the statements of Imam Shatibi in his book almuwafaqāt fi ușul al-shari'ah: "indeed, shäri' (Allah SWT) stipulates shari'ah to realize and actualize the benefit for mankind in the world and the the hereafter". ${ }^{28}$ This is, of course, in line with what BMT Mawaddah has been trying to do, to become a shari'ah economic institution whose goals are not just business oriented and worldly benefits, but more of how to get benefit for the life in the hereafter. This is the one of the reasons of why BMT Mawaddah becomes one of the largest Islamic educational institutions in Madura with a number of students reaching thousands.

Worldly benefits that have been considered by BMT Mawaddah can be seen by providing educational scholarships to several state university students in Indonesia, have financing programs, savings programs and so on. All of which are oriented towards worldly benefits. As for the hereafter benefits that have been pursued by BMT Mawaddah, such as providing financial assistance for the construction and maintenance of several mosques, paying zakat to the poor and so on. These all are oriented towards reaching the benefit of the hereafter. Finally, in this study, the researcher found a match between the Imam Shätibï's statement above with what has been done by BMT Mawaddah regarding the implementation of maqassid

${ }^{28}$ Ibid, 28. 
shari'ah of al-shātibī particularly within the perspective of al-kulliyyāt al-khamsah.

\section{Closing}

First, the implementation of the maintenance of maqāsid shari'ah of al-shātibi perspective of al-kulliyyat al-khamsah carried out by BMT Mawaddah has been going well. This can be seen from its success in organizing many programs and activities related to the maintenance of maqașid shari'ah alshātibi's al-kulliyyāt al-khamsah perspective which always increases every year.

Second, there are several patterns that are not yet implemented in the implementation of maqașid shari'ah of alShātibi's perspective of al-kulliyyāt al-khamsah because there are obstacles behind the failure of the pattern.

Third, based on the results of primary and secondary data analysis as well as existing literatures, there is a form of conformity between the perspective of al-kulliyyat khamsah in Maqāsid Shari'ah of al-Shātibi with the pattern of implementation of programs carried out by BMT Mawaddah, Palengaan, Pamekasan, Madura.

\section{Bibliography}

Abu Ishaq al-Shatibi, Al-Muwafaqat (Saudi Arabia: Wizarah Syuun al-Islamiyah, jilid 1, 7 .

Adhi Maftuhin, dkk.,Gerbong Pemikiran Islam II Kairo: AnNahdlah Press, 2016, 5.

Adiwarman Azwar Karim, Sejarah Pemikiran Ekonomi Islam, Jakarta: PT Raja Grafindo Persada, 2006

Ahmad Imam Mawardi, Fiqh Minoritas fiqh al-Aqliyat dan Evolusi Maqashid al-Syari'ah dari konsep ke pendekatan, Yogyakarta: Lkis, 2010

Ahmad Warson Munawwir, Kamus Al-Munawwir ArabIndonesia Terlengkap Surabaya: Pustaka Progessif, 1997 Ali al-Sayis, Nashi'ah al-Fiqh al-Ijtihad wa atwaruh, Kairo :Majma' al-Buhuts al-Islamiyah,1970, 
Atabik Ali, Kamus Kontemporer, Yogyakarta: Yayasan Ali Maksum, Multi Gaya Grafika, 1996,

Departemen Agama Republik Indonesia, Al-Qur'an dan

Terjemahan, Madinah Munawwarah: Mujamma' al-Malik Fahd li Thiba'at al-Mushaf, 1994.

Fathi al-Daraini, al-Manahij al-Ushuliyah, Damsyik: Dar al-Kitab al-Hadits, 1975

Fathur Rahman, Islam, alih Bahasa Ahsin Muhammad, Bandung: Pustaka , 1984

Ibnu Mansur al-Afriqi, Lisan al-'Arab Beirut: Dar as-sadr, tt, 175. Ismail Muhammad Syah, dkk, Filsafat Hukum Islam, (akarta: Bumi Aksara.1992

Muhammad. Ekonomi Islam, Kontribusi Fundamentalisme Islam untuk Ekonomi Islam, Malang: Empatdua, 2009

Muhammad Syafii Antonio, Dalam kata pengantar buku, Maqasid Shari'ah dalam Ekonomi Islam, Yogyakarta: Smart WR, 2014

Satria Effendi , Ushul Fiqih, Jakarta: Kencana, 2005

Yusuf Qardawi, Membumikan Shari'at Islam, Bandung: Pustaka Mizan, 2003

Ayief Fathurrahman, "Pendekatan Maqasid Shari'ah: Konstruksi Terhadap Pengembangan Ilmu Ekonomi dan Keuangan Islam", Hunafa: Jurnal Studia Islamika, Vol. 11, No. 2 Desember 2014

Ayief Fathurrahman, "Meninjau Ulang Landasan Normatif Perbankan Shari'ah Di Indonesia: Telaah Atas Teori Kontruksi Fikih Klasik", Jurnal Mawarid, Vol. XI, No. 1 Februari-Agustus, 2010

Budi Sukardi, dkk, "Inklusivisme Maqashid Shari'ah Menuju Pembangunan Berkelanjutan Bank Shari'ah di Indonesia”, Tsaqafah, Vol. 12, No. 1 Mei 2016

Galuh Nashrullah, “Konsep Maqasid al-Shari'ah dalam Menentukan Hukum Islam: Perspektif al-Shatibi dan Jasser Auda", Al-Iqtishadiyah, Vol. 1, No. 1 Desember 2014 Khoirul Amin, "Implementasi Maqasid al-Ahkam Terkait Rekonstruksi Hukum Islam Indonesia", Mlangi, Vol. 2, No. 2, Desember 2014 
Operations Of The Institution Of Baitul Mal Wa At-TamwiL ...

Muhammad Abu Zahra, Ushul al-Fiqh, Mesir : Dar al-Fikr al'Arabi, 1958

Muhammad Khalid Mas'ud, Filsafat Hukum Islam dan Perubahan Sosial, terjemahan oleh Yudian W. Asmin, Surabaya: al-Ikhlas, 1995

Muhammad Said Romadhan al-Buthi, Dawa.bit al Maslahah fi al-Shari'ah al-Islamiyah, Beirut: Dar al-Muttahidah, 1992

Muhammad Zaki, "Aplikasi Maqasid Asy-Shari'ah pada Sistem Keuangan Shari'ah", Bisnis, Vol. 3, No. 2 Desember 2015

Zaki Zamani, "Urgensi Maqasid al-Shari'ah dalam Manajemen Perbankan Shari'ah ", JES, Vol. 1, No. 2 Maret, 2017

Zainil Ghulam, "Implementasi Maqasid Shari'ah dalam Koperasi Shari'ah", Iqtishoduna, Vol. 7, No. 1 April, 2016 